\title{
Plant Cryopreservation: A Look at the Present and the Future
}

\author{
Carla Benelli (D)
}

check for

updates

\section{Citation: Benelli, C. Plant}

Cryopreservation: A Look at the

Present and the Future. Plants 2021,

10, 2744. https://doi.org/10.3390/

plants10122744

Received: 2 December 2021

Accepted: 10 December 2021

Published: 13 December 2021

Publisher's Note: MDPI stays neutral with regard to jurisdictional claims in published maps and institutional affiliations.

Copyright: (c) 2021 by the author. Licensee MDPI, Basel, Switzerland. This article is an open access article distributed under the terms and conditions of the Creative Commons Attribution (CC BY) license (https:// creativecommons.org/licenses/by/ $4.0 /)$.
Institute of BioEconomy, National Research Council (CNR/IBE), Sesto Fiorentino, 50019 Florence, Italy; carla.benelli@ibe.cnr.it

Cryopreservation is known as an applied aspect of cryobiology or the study of life at low temperatures. Plant cryopreservation, specifically, is a process of cooling and storing vegetal structure as plant cells, tissues, or organs in liquid nitrogen $\left(\mathrm{LN} ;-196^{\circ} \mathrm{C}\right)$ or $\mathrm{LN}$ vapor $\left(-160^{\circ} \mathrm{C}\right)$. This methodology ensures the maintenance of samples' viability after thawing, and indefinite storage is possible. The cryopreservation technique is based on the removal of all freezable water from tissues by physical or osmotic dehydration, followed by ultrarapid freezing. The ultralow temperature stops metabolic and biochemical reactions in the cell, after adequate dehydration of plant tissues, to prevent the formation of intracellular ice crystals, which can cause cell death and destruction of cell organelles during the freezing process. Cryopreservation is currently the most innovative and affordable biotechnological approach that allows safe long-term conservation of plant biodiversity without risk of genetic modifications. Few events and reports are available in the literature about genetic modifications in cryopreservation and, if they occurred, the exact mechanism and elucidation of the nature of genetic instability was not clarified, considering the multiple stages involved in the process (in vitro culture-cryoprotection-regeneration).

A pioneer in the plant cryopreservation was Prof. Akira Sakai, who reported the survival of mulberry twigs after exposure to liquid nitrogen [1]. However, plant cryopreservation studies took another 20 years to become established as an area of investigation. Since then, the cryopreservation has been disseminated by the development and application of cryogenic procedures, based on the slow cooling system first and then on the two-step cooling system. In particular, the two-step cooling system took over for its easy application, low cost, and less time-consuming procedure aiming at the direct immersion in liquid nitrogen of plant specimens from tissue culture, without resorting to expensive apparatus and with a considerable simplification of procedures. All this has allowed a large-scale application on plant species, with suitable cryopreservation protocols that can provide high plant regrowth after thawing, thus facilitating the establishment of organized and strategic cryobanks of plant genetic resources.

The two-step cooling process is based on the induction of explant "vitrification" during a very fast decrease in temperature [2]."Vitrification" of cells and tissues is the physical process, which avoids intracellular ice crystallization, during ultra-freezing, by the transition of the aqueous solution of the cytosol into an amorphous, glassy state. As a consequence of this process, plant tissues are protected from damage and remain viable during their long-term storage at $-196^{\circ} \mathrm{C}$.

Various vitrification-based techniques have been developed and are available for different plant species such as vitrification, encapsulation-dehydration, encapsulationvitrification, desiccation, [3] and, more recently, droplet vitrification and D or V cryoplate $[4,5]$, but the techniques are an ever-changing skill to improve the plant recovery rates, to expand the number of the cryopreserved species and, above all, working on the species, which are still hard to process with the cryopreservation. For example, in this Special Issue, present is an optimized cryopreservation protocol for embryonic axes of chestnut (Castanea sativa Mill.) developed based on the encapsulation-vitrification procedure; furthermore, the addition of activated charcoal (AC) as a component of the artificial matrix of synthetic 
seeds promoted growth by shortening the development times and limiting the loss of cryopreserved explants [6].

Cryogenic protocols are multi-stage, every step requires care to assure the successful of cryopreservation along with all the investigations connected to them, such as histoanatomical, molecular, and physiological studies and in vitro culture procedures necessary to support recovery of cryopreserved explants.

The continuous research and technological evolution can markedly improve the cryogenic methodologies, allowing to enhance the recovery percentage of the species, as has occurred over the years. The new knowledge offers the prospect of bringing the cryopreservation technique to a superior level for preserving the vitality and integrity of the samples before and after storage. In Stevia rebaudiana, for example, the effectiveness of shoot tips cryopreservation increased with the application of $\mathrm{V}$ cryo-plate procedure, resulting in superior regrowth of $93 \%$, [7] compared to the vitrification procedure applied by Shatnawi et al. [8], which obtained $68 \%$ of shoot tips regrowth. Moreover, new information has been acquired based on investigations in order to improve the explant physiological state, pre-treatment conditions, time and conditions of the cryoprotectant treatments, enhance the cooling and warming rates, and the recovery medium to achieve successful viability and regrowth of cryopreserved species. A contribution to the arduous process of optimizing cryoprotectant formulations in this Special Issue was given. Faltus at al. [9] has described in detail the thermal characteristics of two important plant vitrification solutions (PVS2 and PVS3) and their components depending on their concentration and temperature, while the opportunity of PVS2 modification to provide better application to new species has been dealt with by Zamecnik et al. [10]; support can also come from the Coherent AntiStokes Raman Scattering (CARS) microscopy by facilitating the visualization of deuterated cryoprotectants within living cells [11].

Distinct and adapted cryogenic techniques have been applied to a wide range of explants, including pollen, seeds, somatic and zygotic embryos, suspension or callus culture, apical buds, shoot tips, and dormant buds. The explant choice is also connected to the best in vitro recovery method for a specific genotype after cryopreservation. Hence, it is necessary to have an efficient in vitro regeneration system for a wider application of plant cryopreservation. For vegetatively propagated species, the most widely used organs are shoot tips excised from the in vitro plant $[12,13]$. Using this type of explant, the somaclonal variation is less probable to occur with respect to direct or indirect organogenesis [14]. In some woody species (e.g., apple, pear), using dormant buds as explants has also been developed and applied to cryopreservation protocols, assessing the recovery by grafting $[15,16]$. The dormant bud cryopreservation technique is an efficient alternative to the labor-intensive in vitro shoot tip cryopreservation process, allowing the preservation of large quantities of germplasm in a season [17]. Recently, in the 23 cryopreserved blackcurrant cultivars, using non-desiccated dormant buds collected from a greenhouse, the estimated recovery ranged between 42 and $90 \%$ [18].

Over time, cryopreservation protocols have been established for several hundreds of plant species [3] and further research is being conducted to enable adoption of this approach even more broadly. Currently, over 10,000 accessions starting from in vitro cultures are preserved through cryopreservation methods, and more than $80 \%$ of these belong to five crops: potato, cassava, bananas, mulberry, and garlic. Other important plant cryopreservation collections representing thousands of accessions are those of dormant apple buds [19-21]. Cryopreservation techniques are now used for plant germplasm storage in many institutes around the world [22,23]. The preservation of plant genetic resources (PGRs) is highly important for food security and agrobiodiversity, in breeding programs to obtain new or more productive plants, but also to have plants resistant to abiotic and biotic stresses. The application of advanced biotechnology, such as cryopreservation, represents an efficient alternative method for ex situ conservation of germplasm, and helps overcome several limitations of storage by conventional methods (seed banks and clonal orchards) [24-26]. Cryopreservation can be considered a safe strategy for long-term 
conservation and a backup to field collections to reduce the loss of plant germplasm. In this Special Issue, a protocol for seed cryopreservation and following in vitro germination has been reported for the first time in Eastern Turkeybeard (Xerophyllum asphodeloides (L.) Nutt.), a threatened species that has responded positively to the cryogenic technique [27].

On the other hand, a clear indication that the cryopreservation is a useful and necessary tool for conservation of plant species has also been underlined in the Plant Conservation Report 2020 [28]; this report mentioned the cryopreservation among alternative conservation methods. Several cryopreservation germplasm repositories (cryobanks) have been established for various plant species in different countries (e.g., cassava, potato, banana, apple, pear, coffee, mulberry, garlic), applying different cryopreservation techniques, and this strategy represents a guide for conservation in the future.

However, a few remarks should be made to face this new challenge; specifically, some critical issues need to be overcome and they will be part of the strategy to be pursued over the coming years. Detailed and exhaustive reviews [3,12,29-31] and articles described the various cryogenic methods applied to plants, but although much progress has been accomplished in the last years, some drawbacks still limit the wide use of cryopreservation, and the difficulties and challenges with the aim to further expand its frontiers should be considered.

The cryopreservation practice requires an initial technological investment but the maintenance costs for the application of the different techniques will later be lower, considering that the use of cryopreservation facilitates the storage and rapid multiplication of plant germplasm in a pathogen-free aseptic environment as well as optimization of physical space and labor. In a perspective of conservation strategy, the introduction of an accession into cryopreserved storage is more expensive than establishing an accession in in vitro culture or in the field, but the cryopreservation costs for the long-term vision (over 20 years) are considerably lower than those of maintenance in the field or in vitro, particularly when many accessions are preserved.

The difficulty to transfer technology and validating protocols between laboratories is a key issue [32]. There are some critical factors that involve all the cryopreservation steps such as type of plant materials, conditions of preculture, cryopreservation technique, cooling, warming, and regrowth conditions [13]. The lack of reproducibility available protocols, or the difficulty in adapting them, can be due to numerous causes, ranging from different sources of laboratory supplies to the different equipment and the different levels of technical skills found in cryopreservation laboratories.

The development and dissemination of increasingly simple and well-described protocols [33], with adequate facilities and trained personnel, will allow new challenges in each cryopreservation laboratory or institution as well as the implementation of the cryopreservation procedures in cryobanks and for biological materials and organisms important for research and in applications, including algae [34].

For this reason, it will therefore be essential to carry out joint strategies and programs among different countries to overcome some critical issues and, above all, find large-scale, simple and effective protocols and easily replicable in all laboratories. Accumulating experience in routine procedures, enhancing the skills of staff can be helpful, in addition to proceed with basic research, which should be encouraged (or rather financed) to achieve a better understanding of some topics less investigated.

In conclusion, since there is an increasing importance of plant preservation technology in the modern world, a clear need exists to have reliable methodologies as well as strong research and development activity in cryopreservation to ensure the applications are fit for purpose. The development of simple, reliable and cost-effective methods is essential and advances will be made faster if the know-how will be wide and shared, all this will support the cryopreservation, which is potentially the safest method to maintain vegetative germplasm and recalcitrant seed for a long-time life.

Funding: This research received no external funding. 
Institutional Review Board Statement: Not applicable.

Informed Consent Statement: Not applicable.

Conflicts of Interest: The author declares no conflict of interest.

\section{References}

1. Sakai, A. Survival of plant tissue of super-low temperatures. Low. Temp. Sci. B 1956, 14, 17-23.

2. Benson, E.E. Cryopreservation theory. In Plant Cryopreservation: A Practical Guide; Reed, B.M., Ed.; Springer: New York, NY, USA, 2008; pp. 15-32.

3. Reed, B.M. (Ed.) Cryopreservation-Pratical considerations. In Plant Cryopreservation: A Practical Guide; Springer: New York, NY, USA, 2008; ISBN 978-0-387-72275-7.

4. Yamamoto, S.I.; Rafique, T.; Priyantha, W.S.; Fukui, K.; Matsumoto, T.; Niino, T. Development of a cryopreservation procedure using aluminium cryo-plates. Cryo-Letters 2011, 32, 256-265.

5. Niino, T.; Yamamoto, S.I.; Fukui, K.; Martińez, C.R.C.; Valle Arizaga, M.; Matsumoto, T.; Engelmann, F. Dehydration improves cryopreservation of mat rush (Juncus decipiens Nakai) basal stem buds on cryo-plates. Cryo-Letters 2013, 34, 549-560. [PubMed]

6. Gaidamashvili, M.; Khurtsidze, E.; Kutchava, T.; Lambardi, M.; Benelli, C. Efficient Protocol for Improving the Development of Cryopreserved Embryonic Axes of Chestnut (Castanea sativa Mill.) by Encapsulation-Vitrification. Plants 2021, 10, 231. [CrossRef]

7. Benelli, C.; Carvalho, L.S.O.; EL merzougui, S.; Petruccelli, R. Two Advanced Cryogenic Procedures for Improving Stevia rebaudiana (Bertoni) Cryopreservation. Plants 2021, 10, 277. [CrossRef]

8. Shatnawi, M.A.; Shibli, R.A.; Abu-Romman, S.M.; Al-Mazra'awi, M.S.; Al Ajlouni, Z.I.; Shatanawi, W.A.; Odeh, W.H. Clonal propagation and cryogenic storage of the medicinal plant Stevia rebaudiana. Spanish J. Agric. Res. 2011, 9, 213-220. [CrossRef]

9. Faltus, M.; Bilavcik, A.; Zamecnik, J. Vitrification Ability of Combined and Single Cryoprotective Agents. Plants 2021, 10, 2392. [CrossRef]

10. Zamecnik, J.; Faltus, M.; Bilavcik, A. Vitrification Solutions for Plant Cryopreservation: Modification and Properties. Plants 2021, 10, 2623. [CrossRef]

11. Samuels, F.M.D.; Stich, D.G.; Bonnart, R.; Volk, G.M.; Levinger, N.E. Non-uniform distribution of cryoprotecting agents in rice culture cells measured by cars microscopy. Plants 2021, 10, 589. [CrossRef] [PubMed]

12. Benelli, C.; De Carlo, A.; Engelmann, F. Recent advances in the cryopreservation of shoot-derived germplasm of economically important fruit trees of Actinidia, Diospyros, Malus, Olea, Prunus, Pyrus and Vitis. Biotechnol. Adv. 2013, 31, 175-185. [CrossRef]

13. Bettoni, J.C.; Bonnart, R.; Volk, G.M. Challenges in implementing plant shoot tip cryopreservation technologies. Plant Cell. Tissue Organ Cult. 2021, 144, 21-24. [CrossRef]

14. Scowcroft, W.R. Genetic variability in tissue culture: Impact on germplasm conservation and utilization. In Proceedings of the International Board for Plant Genetic Resources (IBPGR) Technical Report AGPGIBPGR/84/152; IBPGR: Rome, Italy, 1984.

15. Vogiatzi, C.; Grout, B.W.W.; Toldam-Andersen, T.B.; Green, J. Cryopreservation of dormant buds from temperate fruit crops to optimise working collection resources. Acta Hortic. 2011, 908, 477-482. [CrossRef]

16. Bilavcik, A.; Faltus, M.; Zamecnik, J. The Survival of Pear Dormant Buds at Ultra-Low Temperatures. Plants 2021, 10, 2502. [CrossRef]

17. Tanner, J.D.; Chen, K.Y.; Bonnart, R.M.; Minas, I.S.; Volk, G.M. Considerations for large-scale implementation of dormant budwood cryopreservation. Plant Cell. Tissue Organ Cult. 2021, 144, 35-48. [CrossRef]

18. Rantala, S.; Kaseva, J.; Nukari, A.; Laamanen, J.; Veteläinen, M.; Häggman, H.; Karhu, S. Successful Cryopreservation of Dormant Buds of Blackcurrant (Ribes nigrum L.) by Using Greenhouse-Grown Plants and In Vitro Recovery. Plants 2021, 10, 1414. [CrossRef]

19. Volk, G.M.; Waddell, J.; Bonnart, R.; Towill, L.; Ellis, D.; Luffman, M. High viability of dormant Malus buds after 10 years of storage in liquid nitrogen vapour. Cryo-Letters 2008, 29, 89-94.

20. Höfer, M. Cryopreservation of winter-dormant apple buds: Establishment of a duplicate collection of Malus germplasm. Plant Cell. Tissue Organ Cult. 2015, 121, 647-656. [CrossRef]

21. Jenderek, M.M.; Reed, B.M. Cryopreserved storage of clonal germplasm in the USDA National Plant Germplasm System. Vitr. Cell. Dev. Biol.-Plant 2017, 53, 299-308. [CrossRef]

22. Niino, T. Developments in plant genetic resources cryopreservation technologies. Proc. APEC Work. Eff. Gene Bank Manag. APEC Memb. Econ. Suwon Korea 2006, 197-217.

23. Malik, S.K.; Chaudhury, R.; Pritchard, H.W. Long-term, large scale banking of citrus species embryos: Comparisons between cryopreservation and other seed banking temperatures. Cryo-Letters 2012, 33, 453-464. [PubMed]

24. González-Benito, M.E.; Ramírez, I.C.; Aranda, J.M.L. The use of cryoperservation for germplasm conservation of vegetatively propagated crops. Spanish J. Agric. Res. 2004, 3, 341-352. [CrossRef]

25. Paunescu, A. Biotechnology for endangered plant conservation: A critical overview. Rom. Biotechnol. Lett. 2009, 14, 181-202.

26. Ruta, C.; Lambardi, M.; Ozudogru, E.A. Biobanking of vegetable genetic resources by in vitro conservation and cryopreservation. Biodivers. Conserv. 2020, 29, 3495-3532. [CrossRef]

27. Issac, M.; Kuriakose, P.; Leung, S.; Costa, A.B.; Johnson, S.; Bucalo, K.; Stober, J.M.; Determann, R.O.; Rogers, W.L.; Cruse-Sanders, J.M.; et al. Seed Cryopreservation, Germination, and Micropropagation of Eastern Turkeybeard, Xerophyllum asphodeloides (L.) Nutt.: A Threatened Species from the Southeastern United States. Plants 2021, 10, 1462. [CrossRef] [PubMed] 
28. Sharrock, S. Plant Conservation Report 2020: A review of progress in implementation of the Global Strategy for Plant Conservation 2011-2020. Secretariat of the Convention on Biological Diversity, Montréal, Canada and Botanic Gardens Conservation International; Technica: Richmond, UK, 2020; ISBN 9789292257057.

29. Kulus, D.; Zalewska, M. Cryopreservation as a tool used in long-term storage of ornamental species-A review. Sci. Hortic. 2014, 168, 88-107. [CrossRef]

30. O'Brien, C.; Hiti-Bandaralage, J.; Folgado, R.; Hayward, A.; Lahmeyer, S.; Folsom, J.; Mitter, N. Cryopreservation of Woody Crops: The Avocado Case. Plants 2021, 10, 934. [CrossRef]

31. Engelmann, F. Use of biotechnologies for the conservation of plant biodiversity. Vitr. Cell. Dev. Biol.-Plant 2011, 47, 5-16. [CrossRef]

32. Reed, B.M.; Kovalchuk, I.; Kushnarenko, S.; Meier-Dinkel, A.; Schoenweiss, K.; Pluta, S.; Straczynska, K.; Benson, E.E. Evaluation of critical points in technology transfer of cryopreservation protocols to international plant conservation laboratories. Cryo-Letters 2004, 25, 341-352.

33. Engelmann, F. Plant cryopreservation: Progress and prospects. Vitr. Cell. Dev. Biol.-Plant 2004, 40, 427-433. [CrossRef]

34. Li, H.-H.; Lu, J.-L.; Lo, H.-E.; Tsai, S.; Lin, C. Effect of Cryopreservation on Proteins from the Ubiquitous Marine Dinoflagellate Breviolum sp. (Family Symbiodiniaceae). Plants 2021, 10, 1731. [CrossRef] 